\title{
The effect of phonetic transcription on Iranian EFL students' word stress learning
}

\author{
Mohammad Reza Ghorbani ${ }^{\mathrm{a}}$ \\ ${ }^{a}$ University of Bojnord, Kilometr 4 Jade Esfarayen, Bojnord 9453155111, Iran
}

\section{APA Citation:}

Ghorbani, M. R. (2019). The effect of phonetic transcription on Iranian EFL students' word stress learning. Journal of Language and Linguistic Studies, 15(2), 400-410.

\begin{abstract}
The correct location of lexical stress is a main concern for English as a foreign language (EFL) learners whose first language has a different stress system. Therefore, in light of the fact that pronunciation errors in English are often the result of the Farsi language sound system transfer, the present study examined the impact of phonetic transcription on Iranian undergraduate EFL students' word stress learning. The quasi-experimental design was used to study two classes of EFL major students at the University of Bojnord (UB) and Kosar University of Bojnord (KUB) as the experimental group (EG) and control group (CG) respectively. A 60-item word stress test was developed by the researcher based on 20 lessons of The Flatmates from the BBC's learning English website to examine the learners' achievements. The test reliability was determined to be 0.71 through KR-21 formula. The independent samples t-test results indicated that the EG outperformed the CG. Thus, the findings suggest that EFL learners' phonetic transcription can facilitate the process of lexical stress learning.
\end{abstract}

(C) 2019 JLLS and the Authors - Published by JLLS.

Keywords: Lexical stress; pronunciation; phonetic transcription; EFL teaching; phonology

\section{Introduction}

This paper presents phonological experiments designed to demonstrate the use of International Phonetic Alphabet (IPA) transcriptions for promoting increased awareness (explicit learning) of lexical stress patterns for Iranian students of English as a foreign or additional language. The objective is to improve the quality of spoken English in undergraduates in an instructed learning context by working on listening perception.

Information and Communication Technology (ICT) is currently used in almost every aspect of life. The utilization of ICT as a powerful tool for educational change and reform has appealed a significant progress in language learning. According to Hartoyo (2008), it can facilitate language learning.

The researcher is aware of the fact that new developments like the connectionist dual process (CDP) approach to modelling reading aloud by Zorzi (2010) have led to the improved machine-human interfaces and more effective text-to-speech algorithms with important pedagogical implications. These

\footnotetext{
* Corresponding author. Tel.: + 0098-915-384-9506

E-mail address:mrg872@gmail.com
} 
developments have questioned traditional language teaching practices (implicit learning of pronunciation or "learning by osmosis" through large doses of listening) and the confusing role of symbolic representational systems. However, his EFL teaching experience for more than 25 years in Iran, Japan, and Malaysia urged him to employ this method, which seems more efficient and effective in EFL contexts.

According to Ghorbani (2011), since pronunciation does not appear or is not tested in the formal education exams, it is neglected by many Iranian EFL teachers. He argues that lack of English phonemes in Persian, unpredictability of the orthographic system of the English language, and sacrificing teaching pronunciation to spend more time on other language skills by teachers account for Iranian learners' problem in learning the English language pronunciation. He suggests that the relation and correspondence between each symbol and sound can be more clarified by using phonetic transcription.

Explicit phonologically based instruction can help learners achieve decoding and word recognition skills (Snowling \& Hulme, 2011). According to Ziegler and Goswami (2005), orthographic representations are somehow dependent on the phonological forms they represent. That is why successful reading depends upon establishing the phonological connections to orthography. Therefore, it is necessary to have a shift from orthographic analysis of words to phonological analysis so that student errors and difficulties can be well interpreted and effectively remedied (Werfel, 2017)

According to Wenden (1992), empowering learners with learning strategies is one of the language teaching goals. In line with the recent trend in phonetics and language teaching (Ladefoged, 2006; Kelly, 2000), which recommends a task-based instruction of the phonemes of the target language, this study was conducted to scrutinize whether empowering EFL learners with meta-cognitive strategies through phonetic transcription would have any effect on improving the pronunciation of Iranian EFL learners. More specifically, the purpose of this study was to investigate the effect of phonetic transcription on Iranian undergraduate EFL students' word stress learning.

\subsection{Literature review}

Pronunciation is an integral part of teaching foreign languages in general and English in particular. According to Dalton (1997), when the new sounds in the target language are not recognized by the learners, their mind automatically changes them into the sounds which exist and are closest in their mother tongue. The less the difference between the first language (L1) and the foreign/second language (L2), the easier it will be to learn the L2 (Yarmohammadi, 2000).

Although mispronunciation can lead to a conversation failure (Brown, 2007), pronunciation instruction still does not attract enough attention in Iran. Learners' listening and speaking skills are much less emphasized than reading and writing skills in the Iranian formal EFL course-books. In alignment with the books, these skills are rarely tested in the final exams. Furthermore, pronunciation is not a priority for high school teachers (Jahangard, 2007; Hosseini 2007; Razmjo \& Riazi 2006), which, in turn, has led to the Iranian university students' communication failure in English (Farhady, Jafarpoor, \& Birjandi, 1994).

According to Tominaga, (2011), pronunciation is still a peripheral and rarely taught component of EFL classes at Japanese high schools in spite of teachers' and students' awareness of its necessity. However, many techniques have been suggested to help learners master the correct pronunciation of English throughout the world.

According to Hayati (2010), imitation is the first technique. After pronouncing a word several times, the teacher asks the students to listen to and imitate the word carefully. The students usually repeat it first in chorus and then individually. Hayati (2008) suggests repetition as an effective way of familiarizing the learners with foreign accents. According to Okita (1999), many Japanese teachers still 
use this audiolingual technique, which is not in alignment with the Communicative Language Teaching (CLT).

Hayati (2010) mentions explanation as the second technique in which the teacher explains not only the place but also the manner of articulation of the new target language sounds by making extensive and varied use of realia such as pictures and drawings. He suggests comparing the similarities and contrasting the differences as the third technique through which students can learn the sound system of the $\mathrm{L} 2$.

Both the explanation and comparison and contrast techniques have some shortcomings (boring and unnecessary esp. for young learners) that do not solve the problem of EFL students' pronunciation. The mimicry memorization (Mim-Mem) of the audio-lingual method period as a purely mechanical technique is also unpleasant, dull, and monotonous (Hayati, $2010 \& 2008$ ). So, the phonetic transcription technique, which focuses on the words that their sound-to-letter correspondence is not transparent, is examined in this study.

The literature on pronunciation has largely been on what and how of teaching rather than a selfregulated model whereby the students are able to self-monitor their pronunciation through transcribing the sounds of intended words. In line with the recent task-based language teaching trend (Brown, 2007; Nunan 2004), the researcher taught pronunciation explicitly by making the learners aware of the English phonological features. More specifically, this study examines one of the outstanding phonological differences between Persian and English by investigating pronunciation problems facing Iranian EFL learners - lexical stress.

According to Pourhosein Gilakjani (2012), phonetics instruction boosts pronunciation learning. Brown (2001) states achieving an accent-free command of a foreign language is too difficult for many adult learners. To help language learner look up explicit pronunciation information from a dictionary and correct misperceptions, Wells (1996) recommends the transcription of the English language due to its spelling irregularity and direct pronunciation specification. This will reinforce and compensate for what the learners have received imperfectly by ear.

Word stress is one of the most noticeable characteristics of English pronunciation in which one syllable stands out from others. English dictionaries commonly offer three levels of stress, namely primary, secondary, and tertiary. Persian does not have secondary stress and the final syllable receives the accent most of the time. Therefore, an Iranian EFL learner might transfer the Persian accentuation habits into English and place the primary accent on the final syllable. This misplacement can disturb communication or lead to miscommunication.

Correct word stress has a critical role in EFL verbal communication comprehensibility (Murphy, 2004; Celce-Murcia, Brinton, \& Goodwin, 1996) because it contributes to semantic and grammatical changes in words, while in Persian it can rarely cause any difference in meaning and grammatical category. According to Arciuli, Monaghan, \& Seva (2010), over 90\% of all English words include lexical stress. In Persian, stressed and unstressed syllables have the same length while in English they don't. In English, the stress unit is morpheme, while it is word in Persian (Yarmohammadi 1995, 2005).

According to Rafiee (2001), Swan and Smith (2001), and Yarmohammadi (1995), one of the noticeable differences between Persian and English pronunciation is word stress. They argue that since, unlike English, Persian word stress is usually on the final syllable and predictable, Persian-speaking EFL learners find it difficult to learn the stress location of English words. Swan and Smith (2001) assert that since Persian spelling is approximately phonetic, Iranian EFL students usually connect specific letters with specific sounds. They have also suggested that Persian lacks some English vowel sounds. That is why they are so problematic in terms of their pronunciation for Iranian students. 
The degree of predictability in word stress also differs from one language to another. For instance, word stress in Arabic is totally predictable. While word stress in Persian is predictable (on the final syllable) most of the time (Yarmohamadi, 1995), it is almost unpredictable in English. And this is the source of the problem for Iranian students. Although Yarmohamadi (1995), the Iranian phonetician, has formulated a set of rules for English word stress and claims that increase the predictability of the word stress location in English to a large extent, drawing up these predictive rules is so laborious and complicated.

According to Yarmohammadi (2005), due to the trochaic nature of English stress system, Iranian EFL learners usually misplace lexical stress. He argues that this cross-linguistic difference leads to communication interruption and unintelligibility. Based on Heidari Shahreza and Moinzadeh (2012)'s findings, patterns which are musically simulated are more useful for words with two-syllables if the primary stress falls on the second syllable. They suggest that this is probably because of the negative transfer from the Persian language. Therefore, it is necessary to teach these patterns to Iranian EFL learners.

Yu and Andruski (2010) investigated the effect of language background on lexical stress perception in English. They compared 30 native English speakers with 30 native Chinese EFL learners. The participants were asked to identify and discriminate stressed-syllables. The task included real words, pseudo-words, and hums. The findings indicated that both groups were successful in identification and discrimination of stress patterns. However, the English and Chinese speakers were affected differently due to their different response patterns to trochaic (an accented syllable followed by an unaccented syllable) vs. iambic (an unaccented syllable followed by an accented syllable) stress. The researchers' acoustic analysis indicated that different acoustic cues were applied by both groups to process lexical stress suggesting that language background affected lexical stress perception in English.

Based on the Speech Learning Model (SLM), the L2 perception is thought to be a prerequisite to production, and if the difference between the L2 and L1 sounds is great, it is more likely for a learner to discover the phonological difference (Flege, 2002). According to Fullana (2006), this perception-based model is still common in L2 phonological learning research in formal instructional settings.

According to Munro and Derwing (2011), there is not enough evidence to justify the effectiveness of phonetics instruction. Chastain (1976) argued that L2 learners' mispronunciation of sounds is due to their inability to hear them. Sometimes they can hear them but they cannot articulate them. Although contemporary phonetics instruction includes animated diagrams of the vocal tract and employs phonological analysis software to provide visual representations of spectral features (Lord, 2005), it does not seem practical in the research context due to the lack of the required facilities. The present study empirically tested the effect of traditional, classroom-based, explicit phonetics instruction on improving the perceptive skill of Iranian undergraduate EFL learners. More specifically, this study tried to understand whether EFL learners' phonetic transcription could facilitate the process of lexical stress learning

\subsection{Research questions}

Does phonetic transcription enhance Iranian undergraduate EFL students' word stress learning?

\section{Method}

The instruction in the EG provided explicit information aimed at building learners' explicit knowledge of L2 phonology and emphasized the differences between the subjects' source and target 
language phonological systems by highlighting particular features of the L2 sound system. The instruction in the CG merely exposed learners to L2 sounds so that they can find out the related phonological features. The effect of explicit phonetic instruction and transcription was measured against the control condition that provided the same activities as the experimental condition but lacked explicit phonetic instruction and transcription in $\mathrm{L} 2$.

\subsection{Research Design}

Since this research lacked random assignment, quasi-experimental design was used as summarized in the following diagram. The line refers to non-equivalent groups. EG is the experimental group and CG refers to the control group. T1 and T3 indicates the pretests. T2 and T4 refers to the posttests. X means treatment.

\begin{tabular}{|c|c|c|}
\hline $\mathrm{EG}$ & $\mathrm{T} 1$ & $X$ \\
\hline $\mathrm{CG}$ & $\mathrm{T} 3$ & \\
\hline
\end{tabular}

The research hypothesis in this study is as follows:

Ho: Phonetic transcription has no significant effect on Iranian undergraduate EFL students' word stress learning.

\subsection{Sample / Participants}

Originally 36 Iranian undergraduate EFL learners were involved in this study. Two of them were not included in the experiment for different reasons. Of the 34 remaining subjects, 31 were female and three were male. They were EFL major students at the English department at UB and KUB. As Persian speakers, they had already studied English for 7 years at junior and senior high schools. Two classes of the freshmen, who had taken the speaking and listening 1 course, participated in the study. The EG and CG included 16 and 18 students respectively. A pre-test was used to determine the two groups' initial differences at the beginning of the study. The main limitation turned out to be the number of subjects in both group which makes it difficult to generalize the results.

\subsection{Instrument( $s)$}

Twenty lessons of The Flatmates series from the BBC's learning English website were used as the material. The lessons are conversational audio support materials at the intermediate and advanced levels which allow the participants to develop their speaking and listening skills.

The researcher developed a 60-item achievement pre-test. The items included 20 two-syllable, 20 three-syllable, and 20 four-syllable words. The words were taken from the CD scripts and the sample was not randomly spaced across lesson scripts. The subjects put a check mark symbol on the syllable which received the primary stress. All of the 60 items were equally weighted (one point for each correct answer and no negative point for the wrong answer). The pre-test helped the researcher to determine the two groups' initial differences at the beginning of the study. After a six week interval, the pre-test was rearranged and administered to the participants as the post-test. A group of students helped the researcher pilot the test. Based on Kuder-Richardson Formula 21, the reliability of the test was 0.71 . 


\subsection{Data collection procedures}

In this study two undergraduate first-semester university classes were compared. Before starting the instructions, the teacher gave some overall explanations about the materials and what the subjects were expected to do in each session. After the pre-test, the study was carried out at UB and KUB in 10 sessions. Each session took 90 minutes.

The participants in the EG were required to look the highlighted words up from their Longman dictionaries and write their phonetic transcriptions down. They were to do collaborative work so that they could compare their transcribed words. The teacher (researcher) expected them to know about the right location of primary stress of words and emphasized it explicitly. After explaining the articulation of specific phonemes, the researcher asked the subjects to pronounce the words while looking at their transcription. They could ask the teacher for assistance where necessary. The participants in the CG were not allowed to use their dictionaries. They were expected to deduce the exact pronunciation and stress location of the highlighted words from the "listen and repeat" practice. Twenty episodes were taught to the two groups. Seven days after the experiment, the students took the post-test. The treatment procedure was as follows:

The training session was began on September 22 and ended on November 9, 2013. Since it was a four-unit course, two sessions of 90 minute classes met two days a week. Only 45 minutes of each session was dedicated to the treatment for the purpose of research and the rest to other activities. In the first two sessions, the phonetic symbols and stress locations were instructed in both classes. The researcher read each episode aloud only once. Then, the learners were asked to listen to the $\mathrm{CD}$ version of the lesson one more time.

After listening to the CD version of the lesson, the learners in the EG had enough time to get ready. They had already been provided with Longman pocket dictionaries to work collaboratively and complete their tasks (looking the highlighted words up and writing their phonetic transcriptions down). After listening to the $\mathrm{CD}$, the subjects in the $\mathrm{CG}$ were just required to listen to and repeat after the teacher the whole dialogue two more times in groups. They had already been asked to pay close attention to the stress location of the highlighted words. Then, the teacher enunciated the highlighted words out of the context and asked the students to repeat them individually once more.

The two groups had to recall the details. After reviewing the lessons in their group for three to five minutes depending on the difficulty level of the dialogue, they would act them out for the whole class. The researcher and their classmates were allowed to help them if need be. While the EG spent some time on phonetic transcription of the highlighted words, the CG spent the same amount of time on listening to and repeating them in groups and individually. It was easy to engage the learners and provide a good classroom environment due to the small number of subjects.

The researcher took important steps to decrease or control the influence of extraneous variables as much as possible. Due to a 45 day interval between the pre-test and post-test, the subjects' memory was less likely to influence the outcome. To control the John Henry Effect, arrangements were made so that the subjects in the CG could not discover they were compared with those in the EG.

Cooperative learning recommendations by Johnson and Johnson $(1999 ; 1995 ; 1989)$ were followed in this research. Learners' scores were positively interdependent. No learner dominated the group. Each individual was accountable. Simultaneous interaction, interpersonal skill, and group processing were encouraged. 


\section{Results}

To answer the research question (Does phonetic transcription enhance Iranian undergraduate EFL students' word stress learning?), the pre-test and post-test raw scores were analyzed by the computer software Statistical Package of Social Sciences (SPSS version 18), using an independent samples t-test. The calculation revealed that phonetic transcription has a significant impact on Iranian undergraduate EFL learners' word stress learning. Tables 1 and 2 shows the summary of the t-tests.

Table 1. The Independent Samples t-test for the EG and CG (pre-test)

\begin{tabular}{lcccccc}
\hline Group & $\mathrm{N}$ & Mean & Std Dev & df & $\mathrm{t}$ & Sig. \\
\hline Experimental & 16 & 15.50 & 2.52 & 32 & -0.44 & 0.66 \\
Control & 18 & 15.88 & 2.58 & & & \\
\hline
\end{tabular}

After checking the Levene's test $(\mathrm{p} .=0.91>0.05)$, the results were summarized. As shown in Table 1 , there was no significant difference between the EG $(M=15.50, S D=2.52)$ and the CG $[M=1.88$, $S D=2.58 ; t(44)=0.66, p .>.05]$ before the treatment.

Table 2. The Independent Samples t-test for the EG and CG (post-test)

\begin{tabular}{lcccccc}
\hline Group & $\mathrm{N}$ & Mean & Std Dev & df & t & Sig. \\
& & & & & & \\
\hline Experimental & 16 & 48.62 & 6.46 & 24.86 & 6.28 & $0.000^{*}$ \\
Control & 18 & 36.77 & 4.10 & & & \\
\hline
\end{tabular}

*Sig. $\mathrm{p}<.05$

After checking the Levene's test ( $\mathrm{p} .=0.02<.05)$, the results were summarized. As shown in Table 2, there was a significant difference between the $E G(M=48.62, S D=6.46)$ and the $C G[M=36.77$, $\mathrm{SD}=4.10 ; \mathrm{t}(6.28)=0.000, \mathrm{p}<.05]$. The null hypothesis (phonetic transcription has no significant impact on Iranian undergraduate EFL learners' word stress learning) fail to be accepted. Thus, the effectiveness of phonetic transcription is supported.

\section{Conclusion and Discussion}

Pronunciation in general and stress in particular have been neglected in Iran's EFL academic and scholastic institutions for years. Iranian EFL learners tend to place the primary stress on the final syllable of words due to transfer and overgeneralization of the Persian language accentuation habits into English. This misplacement can disturb communication or lead to miscommunication.

This study was an attempt to substantiate whether phonetic transcription has a positive impact on Iranian undergraduate EFL students' word stress learning. The hypothesis that the learners' phonetic transcription would result in improvement in their word stress learning was confirmed. The EG group exhibited substantial gains in comparison to the CG. The findings of the study confirms the effectiveness of the transcription technique and somehow lend further support to the SLM claim that a target-like perception of the L2 sounds can lead to a target-like production of them. They support Werfel (2017)'s suggestion that shifting from letters to sounds and analyzing the phoneme-to-grapheme correspondence is an effective method for adults. 
Based on the subjects' questions and the researchers' observations during the treatment as well as the analysis of the subjects' performance on the test, it was revealed that in proportion to the number of syllables, the students found it more difficult to identify the place of primary stress. That is, the higher the number of syllables, the harder for the students to mark the location of stress correctly. This is in keeping with Heidari Shahreza and Moinzadeh (2012)'s findings in which musically simulated patterns are more useful for words with two-syllables if the primary stress falls on the second syllable.

The findings are also in line with Yu and Andruski (2010)'s study that language background influences the English language word stress perception. They are, furthermore, in alignment with Yarmohammadi (2005)'s findings that due to the trochaic nature of English stress system Iranian EFL learners misplace lexical stress and mistakenly place the primary stress on the final syllable of English words.

Finally, the findings are in agreement with Wells (1996)'s argument that transcription of a word or an utterance reinforces the learners' correct perceptions. They also support Pourhosein Gilakjani (2012)'s findings that phonetics instruction improves pronunciation learning. Interpreting these findings in light of Werfel (2017), it seems that learning and using phonetic transcription of words is necessary for adults only. This method will probably have different results if it is applied for young learners. Biologically speaking, children are able to automatically perceive new sounds because of their age just by being exposed to the target language. Based on the critical period hypothesis claim (Lenneberg 1967), the optimal period for acquiring a language ends at puberty. Unlike children, adult learners have to analyze the target sounds and words to learn them. That is, exposure alone will not do.

\section{Implications}

Depending on the learners' age, raising their awareness of the target language phonology has been suggested through different methods. Since graphemes and phonemes of the English and Persian languages are different, Iranian EFL learners face challenges regarding perception and production of the English language sounds that cannot be found in Persian. In this study, phonetic transcription at the university level proved to be useful.

As reported by Ghorbani (2011), Ghorbani, Neissari and Kargozari (2016) and Ghorbani and Neissari (2015), pronunciation is rarely taught and tested in the Iranian educational system mainly because of the washback impact of the tests. Other reported reasons for this negligence include lack of time, teachers' low proficiency, lack of phonetic transcription in the available material, and the assumption that learning accurate pronunciation is possible only through listening to native speakers.

As parents, principals, teachers, and students alike prefer better results in the exams in which pronunciation is rarely tested and evaluated, allocating time to its teaching, which has little effect on the students' performance in the current educational system, is deemed as an extra burden to the students. Since phonetic transcription is quite feasible in EFL classes, material developers and ELT writers can use it in their English textbooks to encourage instructors to teach lexical stress pattern of the English language. This is an area which is worth further research.

Some limitations restrict generalization of this study findings. The subjects were merely assessed based on their performance on the word stress written test. Future studies can undertake a similar experiment using oral tests to measure the effect of phonetic transcription on EFL students' word stress learning. The small population of the subjects in this study limits the generalization of its findings. To generalize them, further research with a larger population over a longer period of time is in order. Since 
EFL word stress problem is not confined to the Persian speakers, only, pedagogical techniques and solutions should be sought from other research findings around the world as well to alleviate this difficulty. Very few studies have been done on contrastive analysis of sentential stress (an area closely associated with lexical stress) in English and Persian; therefore, it is strongly recommended that other researchers should fill this gap.

Although this study was small in scale, it still shed some light on the pronunciation problems of Iranian EFL learners. The findings of this research have implications for all EFL contexts by indicating that phonetic transcription as a teaching method in the classroom can reinforce the recognition of the target language sounds imperfectly received by the learners' ear.

\section{References}

Arciuli, J., Monaghan, P. \& Seva, N. (2010). Learning to assign lexical stress duringreading aloud: Corpus, behavioral, and computational investigations .Journal of Memory and Language, 63(2), 180-196.

Brown, D. (2001). Teaching by principles: An interactive approach to language pedagogy (2nd edition). USA: Addison Wesely Longman, Inc.

Brown, H. D. (2007). Principles of language learning and teaching (5th ed.). NewYork: Pearson.

Celce-Murcia, M., Brinton, D., \& Goodwin, J. (1996). Teaching pronunciation: A reference for teachers of English to speakers of other languages. New York: Cambridge University Press.

Chastain, K. (1976). Developing Second Language Skills: Theory to Practice. Chicago: Rand McNally Publishing Co.

Dalton, D.F. (1997). Some techniques for listening pronunciation. The Internet TESL Journal. 3(1). Available online at http://iteslj.org/.

Farhady, H., Jafarpoor, A., \& Birjandi, P. (1994). Testing language skills: From theory to practice. Tehran: SAMT Publications.

Flege, J.E. (2002). Interactions between the Native and Second-language Phonetic Systems. In Burmeister, P., Piske, T. \& Rohde, A. (Eds.), An Integrated View of Language Development: Papers in Honor of Henning Wode (pp. 217-244). Trier: Wissenschaftlicher Verlag.

Fullana, N. (2006). The Development of English (FL) Perception and Production Skills: Starting Age and Exposure Effects. In Muñoz, C. (Ed.), Age and the Rate of Foreign Language Learning (pp. 41-64). Clevedon: Multilingual Matters.

Ghorbani, M. R. (2011). The impact of phonetic instruction on Iranian students' listening ability enhancement. Asian EFL Journal, 52, 24-34.

Ghorbani, M. R., Neissari, M. \& Kargozari, H. R. (2016). The effect of explicit pronunciation instruction on undergraduate English as a foreign language learners' vowel perception. Language and Literacy, 18(1), 57-70.

Ghorbani, M. R. \& Neissari, M. (2015). Washback effect of the Iranian concours on senior high school students' EFL learning activities. Iranian Journal of Language Testing, 5(1), 1-28.

Hartoyo (2008). Individual Differences in Computer-Assisted Language Learning. Semarang: Pelita Insani Semarang. 
Heidari Shahreza, M. A. \& Moinzadeh, A. (2012). Teaching Word Stress Patterns Of English Using A Musically-simulated Technique GEMA Online ${ }^{\mathrm{TM}}$ Journal of Language Studies, 12(2), 521-537.

Hayati, A. M. (2010). Notes on teaching English pronunciation to EFL learners: A case of Iranian high school students. English Language Teaching, 3(4), 121-126.

Hayati, A.M. (2008). Teaching English pronunciation to Iranian students: Problems and suggestions. Available online at http://www.esljournal.org/62926768.html

Hosseini, S. M. H. (2007). ELT in higher education in Iran and India - A critical view.Language in India, 7, 1-11.Retrieved October 9, 2008, from http://www. languageinindia.com /dec2007/eltinindiaandiran.pdf

Jahangard, A. (2007). Evaluation of EFL materials taught at Iranian public high schools. The Asian EFL Journal, 9 (2), 130-150.

Kelly, G. (2000). How to teach pronunciation. Malaysia: Pearson Education Ltd.

Ladefoged, P. (2006). A course in phonetics (5th ed.). Forth Worth: Harcourt, Brace, Jovanovich.

Lenneberg, E. H. (1967). Biological foundations of language. New York: John Wiley \& Sons, Inc.

Lord, G. (2005). (How) Can we teach Foreign language pronunciation? On the effects of a Spanish phonetics course. Hispania, 88(3), 557-567.

Murphy, J.M. (2004). Attending to word-stress while learning new vocabulary. English for Specific Purposes Journal, 24(3), 756-766.

Nunan, D. (2004). Task-based language teaching. Cambridge, UK: Cambridge University Press.

Okita, Y. (1999). Teaching Pronunciation. English Teaching Forum. 37(1), p.16. dosfan.lib.uic.edu/usia/E-USIA/forum/vols/vol37/no1/p16.htm.

Pourhosein Gilakjani, A. (2012). The significance of pronunciation teaching in English language teaching. English Language Teaching 5, 96-107.

Rafiee, A. (2001). Colloquial Persian: The complete course for beginners. London: Rutledge.

Snowling, M. J. \& Hulme, C. (2011). Evidence-based interventions for reading and language difficulties: creating a virtuous circle. British Journal of Educational Psychology, 81(1), 1-23.

Swan, M., \& Smith, B. (2001). Learner English: A teacher's guide to interference and other problems, (Vol. 1). United Kingdom: Cambridge University Press.

Razmjo, S. A. \& Riazi, M. (2006). Is communicative language teaching practical in the expanding circle? A case study of teachers of Shiraz high schools and institutes. Journal of Language and Learning, 4 (2), 144-171.

Tominaga, Y. (2011). An analysis of English pronunciation of Japanese learners: From the viewpoint of EIL. Journal of Pan-Pacific Association of Applied Linguistics, 15(2), 45-57.

Wells, J.C. (1996). Why phonetic transcription is important. Journal of the Phonetic Society of Korea, $31(32), 239-242$.

Werfel, K. L. (2017). Phonetic transcription training improves adults' explicit phonemic awareness: Evidence from undergraduate students. Communication Disorders Quarterly 39(1) 281-287.

Wenden, A. (1992). Learner strategies for learner autonomy. Englewood Cliffs, NJ: Prentice-Hall. 
Yarmohammadi, L. (2005). A contrastive phonological analysis of English and Persian. ( $3^{\text {rd }}$ ed.). Shiraz: Shiraz University Press.

Yarmohammadi, L. 2000. A contrastive phonological analysis of English and Persian. Iran: Shiraz University Press.

Yarmohammadi, L. (1995). A contrastive phonological analysis of English and Persian: A course book in applied phonological studies. Shiraz: Shiraz University Press.

Yu, V. Y., \& Andruski, J. E. (2010). A cross-language study of perception of lexical stress in English. Journal of Psycholinguist Research, 39(4), 323-344.

Ziegler, J. C. \& Goswami, U. (2005). Reading acquisition, developmental dyslexia, and skilled reading across languages: a psycholinguistic grain size theory. Psychological Bulletin, 131(1), 329.

Zorzi, M. (2010). The connectionist dual process (CDP) approach to modelling reading aloud. European Journal of Cognitive Psychology, 22(5), 836-860.

\section{Fonetik transkripsiyonun İran EFL öğrencilerinin kelime vurgusu öğrenmelerine etkisi}

\section{$\ddot{O} \mathbf{z}$}

Sözcüksel vurgunun doğru konumu, İngilizceyi yabancı dil (EFL) olarak öğrenen ve ilk dili farklı bir vurgu sistemine sahip olan öğrenciler için temel bir endişe kaynağıdır. Bu nedenle, İngilizce'deki telaffuz hatalarının genellikle Farsça ses sistemi aktarımının bir sonucu olduğu gerçeği ışığında, bu çalışma fonetik transkripsiyonun İranlı, İngilizceyi yabancı dil olarak öğrene lisans öğrencilerinin kelime vurgusu öğrenmesi üzerindeki etkisini incelemektedir. Yarı deneysel tasarım, deney grubu (EG) ve kontrol grubu (CG) olarak sirasıyla Bojnord Üniversitesi'ndeki (UB) ve Kosar Üniversitesi Bojnord Üniversitesi'ndeki (KUB) iki EFL öğrencisini incelemek için kullanılmıştır. Araştırmacı tarafından, BBC'nin İngilizce öğrenen web sitesindeki 20 The Flatmates dersi alınarak, öğrencilerin başarılarını incelemek amacıyla 60 maddelik bir vurgu testi geliştirilmiş̧ir. Test güvenirliği, KR-21 formülü ile 0.71 olarak belirlenmiştir. Bağımsız örnekler t-testi sonuçları, EG'nin CG'yi geride bıraktığını gösterdi. Bu nedenle, bulgular EFL öğrenenlerinin fonetik transkripsiyonunun sözcüksel vurguyu öğrenme sürecini kolaylaştırabileceğini göstermektedir.

Anahtar sözcükler: Sözcüksel stres; telaffuz; fonetik transkripsiyon; EFL öğretimi; fonoloji

\section{AUTHOR BIODATA}

Dr. Mohammad Reza Ghorbani is Associate Professor of Teaching English as a Second Language (TESL) at the University of Bojnord (UB), Bojnord, Iran. He has worked as an EFL teacher and researcher in Iran, Japan, and Malaysia since 1990. He has published four books on educational issues and three in Germany as well as 26 articles in specialized international journals. He has also presented 11 papers in national and international conferences. His interests are English Teaching, Learning, Testing, and Evaluation. He is currently vice-president for student affairs at at UB. 